International Journal of Automotive and Mechanical Engineering ISSN: 2229-8649 (Print); ISSN: 2180-1606 (Online)

Volume 15, Issue 2 pp. 5295-5307 June 2018

(C) Universiti Malaysia Pahang, Malaysia

DOI: https://doi.org/10.15282/ijame.15.2.2018.11.0408

\title{
An Adaptive Neuro-Fuzzy Inference System (ANFIS) for Wire-EDM of Ballistic Grade Aluminium Alloy
}

\author{
T. Singh ${ }^{1}$, J. P. Misra ${ }^{1 *}$, V. Upadhyay ${ }^{2}$ and P. S. Rao ${ }^{3}$ \\ ${ }^{1}$ Mechanical Engineering Department, NIT Kurukshetra, India \\ *Email: joyprakash.misra@gmail.com \\ ${ }^{2}$ Mechanical Engineering Department, NIT Patna, India \\ ${ }^{3}$ Mechanical Engineering Department, NITTTR Chandigarh, India
}

\begin{abstract}
Intricacy and complexity of ballistic missile and aerospace parts makes WEDM an essential machining process. The current study aims to formulate an ANFIS model for Wire-EDM of ballistic grade aluminium alloy. The experimentation has been conducted with four input variables namely pulse on time $\left(\mathrm{T}_{\text {on }}\right)$, pulse off time $\left(\mathrm{T}_{\text {off }}\right)$, peak current $\left(\mathrm{I}_{\mathrm{p}}\right)$, and servo voltage $\left(\mathrm{V}_{\mathrm{s}}\right)$. Material removal rate $(\mathrm{MRR})$ is employed as process performance evaluator. The values predicted by the developed model are found closer to experimental outcome and thus ensures the model suitability for prediction purpose and intelligent manufacturing. Machined surfaces are also examined by the scanning electron microscope (SEM) to obtain better insight of the process.
\end{abstract}

Keywords: AA 6063; wire-EDM; MRR; ANFIS.

\section{INTRODUCTION}

WEDM is the most emerging non-conventional machining process. It is employed to produce components of tricky profiles. Hence, industries like aerospace, medical implants, electronic, automobile widely use this unique technique. In WEDM, material is removed by a series of sparks between workpiece and wire-electrode submerged in a dielectric fluid (generally, deionized water) and connected to a pulsed DC supply [1,2]. For proper tension of wire-electrode mechanical devices are used. Because of positive and negative polarity of electrodes a stress is generated which affects the dielectric fluid atoms. The ionization of dielectric fluid do not occur until electrode to workpiece voltage and dimension are equal to the dielectric strength rating of the dielectric fluid. At this point, ionization occurs and electron from negative to positive polarity flows through the ionized channel of dielectric fluid. Once ionization takes place, the dielectric become heated from the flow of electron and then converted into plasma. Under this condition electrons from negatively charged electrode rapidly pass through the ionized plasma in the form of spark. High velocity electron collides with workpiece and produce spark, and this spark removes small amount of material from workpiece by melting and vaporizing [3-6]. The detail of process parameters, mechanism of material removal and influence of process parameters on measures of process performance are available in literatures [7-10]. A comprehensive study of published research works has been executed (as shown in Figure 1) on the basis of materials used as workpiece and the modelling technique employed. It is apparent from the study that most of the research works has been carried out for steel based alloys (approx. 46\%); minimum amount of research work has been carried out for aluminium alloys (approx. 11\%). 
Furthermore, Taguchi technique is the most commonly used optimization/modelling technique while only $3 \%$ research works are reported for modelling with ANFIS [1121].
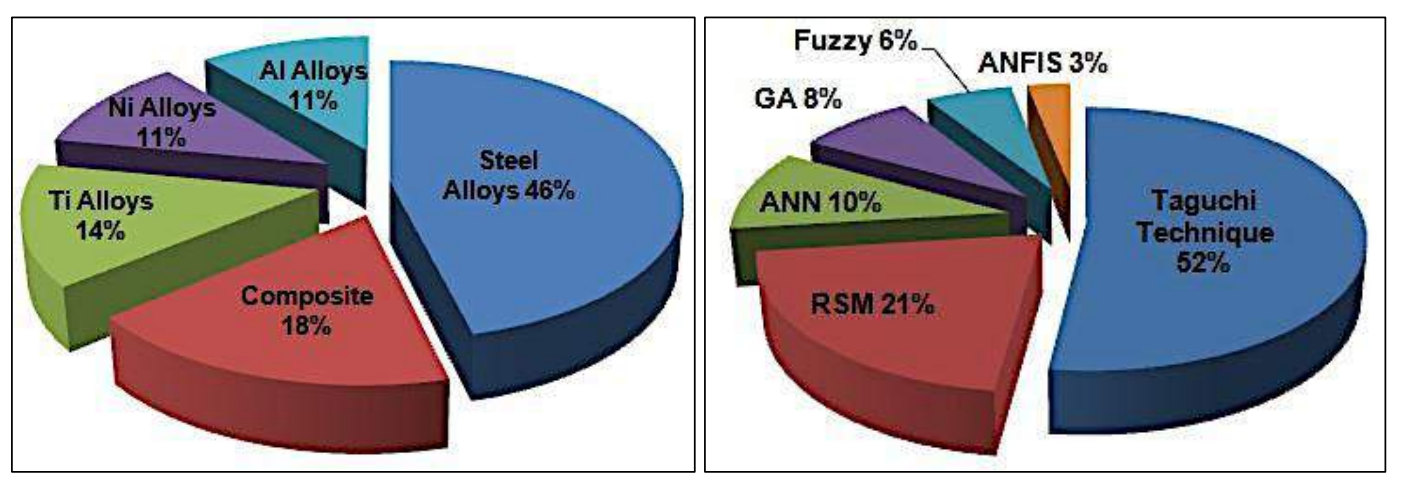

Figure 1. Comparative study of published research works on workpiece materials and modelling techniques

The present day practice is to shorten the product development time and expedite the production process to reduce the overall cost and encash the early product launch in the market. In machining processes, the machining time can be reduced significantly by increasing the MRR to the extent where it does not cause any adverse effect on the surface integrity. An ANFIS model was developed for MRR during wireEDM of ballistic grade aluminium alloy for the potential users of the process.

\section{EXPERIMENTAL DETAILS}

Aluminium Alloy 6063 (AA 6063) is an Al-Si-Mg based alloy having low density, good corrosion resistance, excellent impact strength, energy absorption and stiffness properties and hence, it is best suited for armour applications. EDX image of AA 6063 is shown in Figure 2. AA 6063 has been chosen as workpiece material for this research work [22, 23]. A diffused brass-wire $(\Phi 0.25 \mathrm{~mm})$ and de-ionized water are opted as tool-electrode and dielectric fluid respectively.

Figure 3 illustrates the schematic diagram of machine setup and photographic view of worksamples. Experimentation has been conducted on WEDM setup (Make: Electronica Machine Tool). This setup consists of four major sub-elements:
a) Power supply system,
b) Dielectric system,
c) Positioning system, and
d) Drive system.

$\mathrm{T}_{\mathrm{on}}, \mathrm{T}_{\mathrm{off}}, \mathrm{I}_{\mathrm{p}}$ and $\mathrm{V}_{\mathrm{s}}$ are employed as input process parameters. Table 1 shows the values of input process parameters. Parameters kept fixed for main-experimentation are also presented in Table 1. 


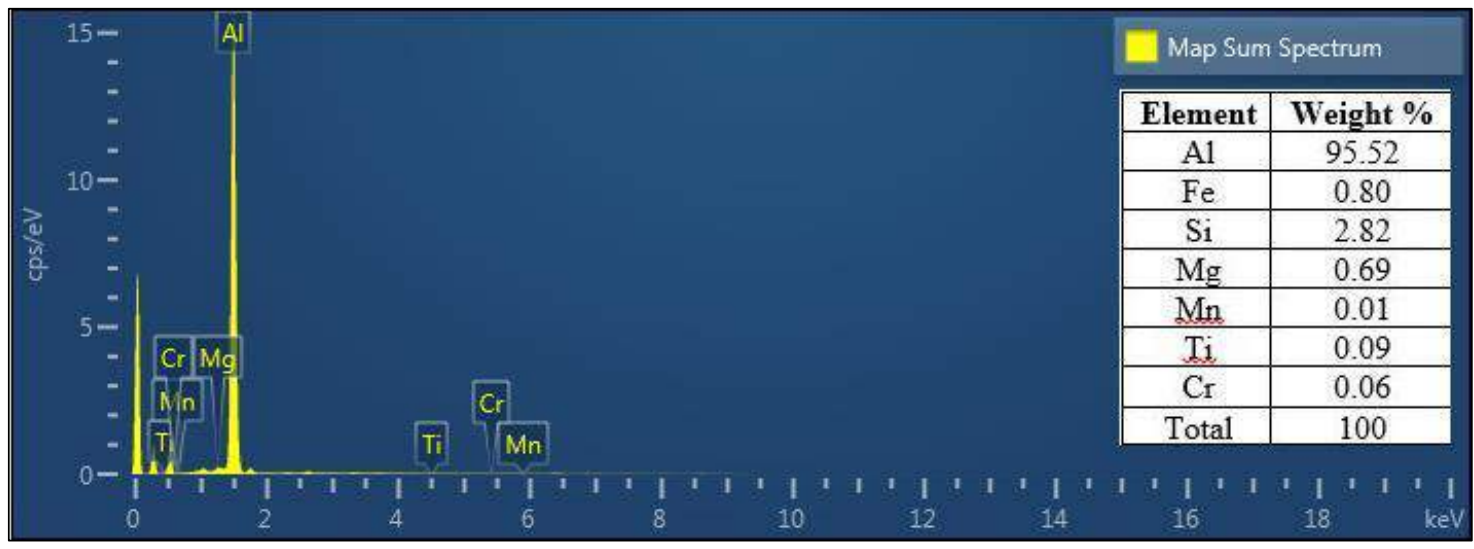

Figure 2. EDX analysis of AA 6063.

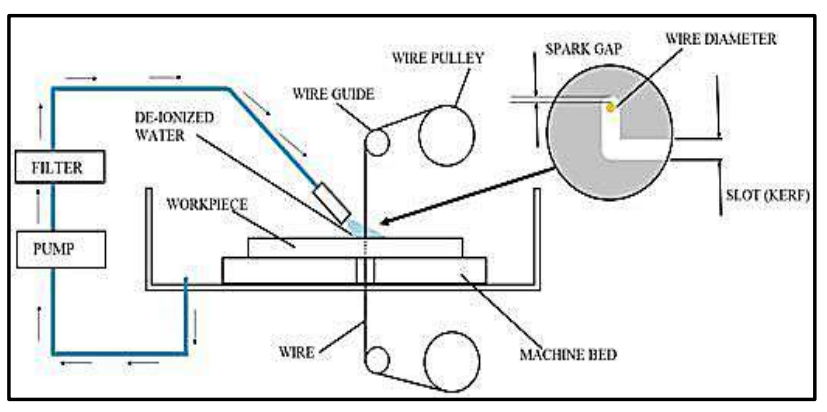

(a) Schematic diagram of WEDM

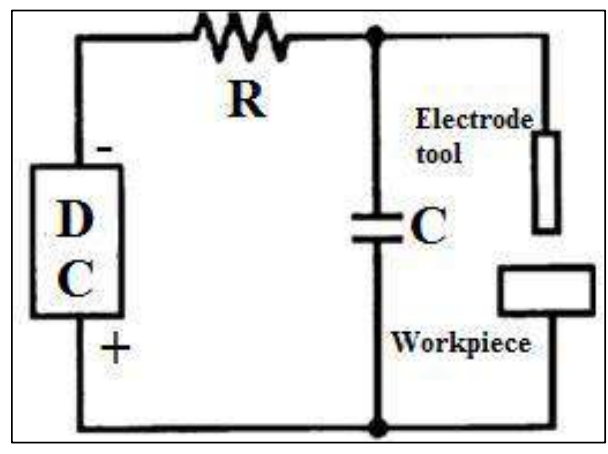

(b) RC pulse generator

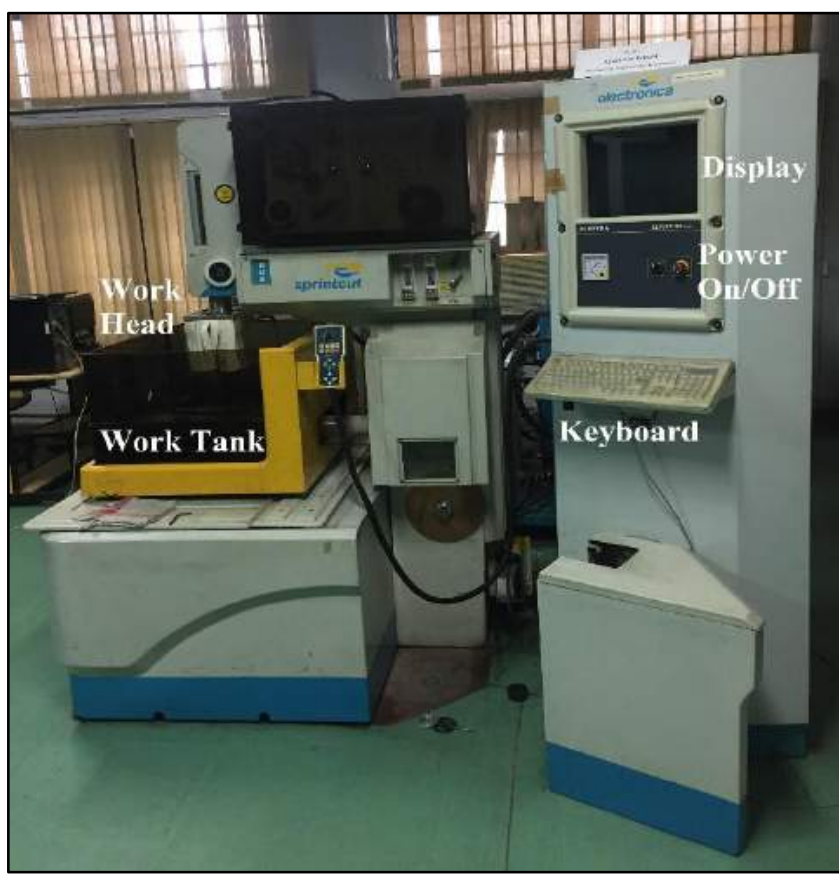

(c) Photographic view of WEDM

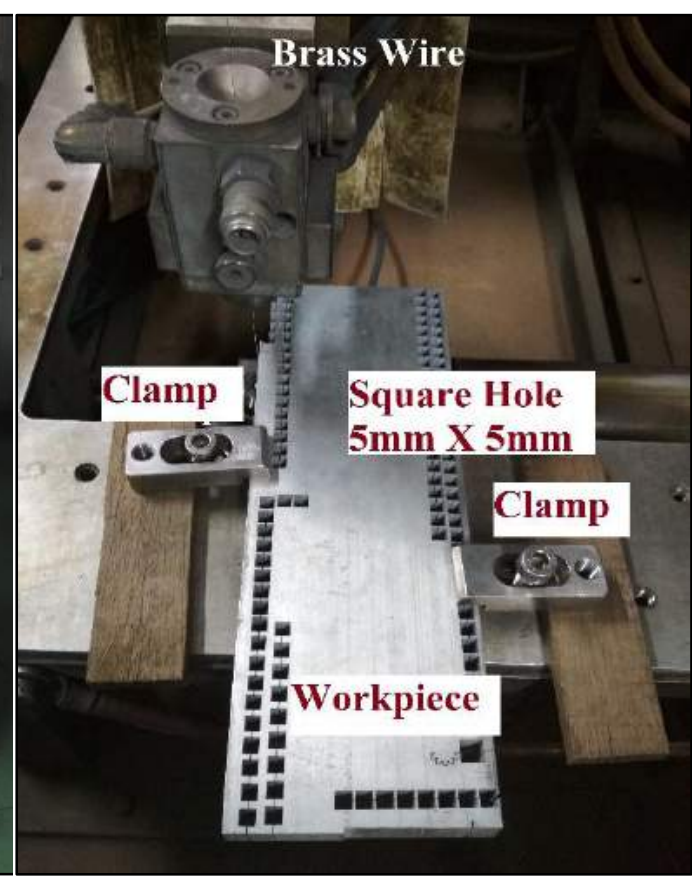

(d) Machining zone of WEDM

Figure 3. WEDM machine setup. 
Table 1. Levels and values of input and fixed parameters

\begin{tabular}{|c|c|c|c|c|c|c|}
\hline \multicolumn{4}{|c|}{ Input process parameters } & \multicolumn{3}{|c|}{ Fixed process parameters } \\
\hline Parameters & L1 & $\begin{array}{l}\text { Levels } \\
\text { L2 }\end{array}$ & L3 & Parameters & Value & $\begin{array}{l}\text { Fixing } \\
\text { criteria }\end{array}$ \\
\hline $\mathrm{T}_{\text {on }}$ & $105 \mu \mathrm{s}$ & $115 \mu \mathrm{s}$ & $125 \mu \mathrm{s}$ & Dielectric fluid & De-ionized Water & \\
\hline $\mathrm{T}_{\text {off }}$ & $40 \mu \mathrm{s}$ & $50 \mu \mathrm{s}$ & $60 \mu \mathrm{s}$ & $\begin{array}{c}\text { Peak Voltage } \\
\text { Water Pressure } \\
\text { Wire Feed }\end{array}$ & $\begin{array}{l}2 \mathrm{~m} / \mathrm{c} \text { unit } \\
1 \mathrm{~m} / \mathrm{c} \text { unit } \\
7 \mathrm{~m} / \mathrm{c} \text { unit }\end{array}$ & $\begin{array}{l}\text { Literature } \\
\text { review and } \\
\text { pilot }\end{array}$ \\
\hline $\mathrm{I}_{\mathrm{p}}$ & $130 \mathrm{~A}$ & $150 \mathrm{~A}$ & $170 \mathrm{~A}$ & $\begin{array}{c}\text { Wire Tension } \\
\text { Servo Feed }\end{array}$ & $\begin{array}{c}7 \mathrm{~m} / \mathrm{c} \text { unit } \\
2050 \mathrm{~m} / \mathrm{c} \text { unit }\end{array}$ & experiments \\
\hline $\mathrm{V}_{\mathrm{s}}$ & $40 \mathrm{~V}$ & $60 \mathrm{~V}$ & $80 \mathrm{~V}$ & $\begin{array}{c}\text { Workpiece } \\
\text { material }\end{array}$ & $\begin{array}{l}\text { AA } 6063(15 \mathrm{~cm} \\
\times 10 \mathrm{~cm} \times 1.5 \mathrm{~cm})\end{array}$ & $\begin{array}{l}\text { Industrial } \\
\text { application }\end{array}$ \\
\hline
\end{tabular}
Eq. (1).

The MRR is opted as process performance characteristic. It is quantified using

$$
\begin{aligned}
\operatorname{MRR}\left(\mathrm{mm}^{3} / \mathrm{min}\right)= & \text { cutting speed }(\mathrm{mm} / \mathrm{min}) \times \text { height of workpiece }(\mathrm{mm}) \\
& \times \text { kerf width }(\mathrm{mm})
\end{aligned}
$$

The experimental runs were designed according to $3^{k}$ full factorial design ( $k$ is number of controlled variables; for present study it is 4). The primary purpose of using the full factorial design is to explore the entire design space with equal accuracy as there is always some error associated with the statistical models. The secondary purpose is to generate enough data to develop the ANFIS model.

\section{RESULTS AND DISCUSSION}

The parametric setting of different trial runs and the value of resulting MRR is presented in Table 2. It is evident from Table 2 that maximum MRR of $18.103 \mathrm{~mm}^{3} / \mathrm{min}$ is achieved for the experimental run where, $T_{\text {on }}=115 \mu \mathrm{s}, T_{\text {off }}=40 \mu \mathrm{s}, I_{p}=150 \mathrm{~A}$, and $\mathrm{V}_{\mathrm{s}}=40 \mathrm{~V}$. On the other hand, the minimum MRR of $1.141 \mathrm{~mm}^{3} / \mathrm{min}$ is obtained for the experimental run where, $T_{\text {on }}=105 \mu \mathrm{s}, T_{\text {off }}=60 \mu \mathrm{s}, I_{p}=170 \mathrm{~A}$, and $\mathrm{V}_{\mathrm{s}}=80 \mathrm{~V}$. It is apparent that there is near about $94 \%$ improvement in MRR value owing to suitable setting of machining parameters. Furthermore, no wire breakage is observed during the experimental investigation.

Table 2. Training data set for ANFIS

\begin{tabular}{ccccccc}
\hline Trial No & $\mathrm{T}_{\text {on }}(\mu \mathrm{s})$ & $\mathrm{T}_{\text {off }}(\mu \mathrm{s})$ & $\mathrm{I}_{\mathrm{P}}(\mathrm{A})$ & $\mathrm{V}_{\mathrm{s}}(\mathrm{V})$ & $\begin{array}{c}\text { Machining time } \\
(\mathrm{min})\end{array}$ & $\begin{array}{c}\text { MRR } \\
\left(\mathrm{mm}^{3} / \mathrm{min}\right)\end{array}$ \\
\hline 1 & 105 & 40 & 130 & 40 & 10.18 & 7.735 \\
2 & 105 & 40 & 150 & 40 & 9.47 & 8.315 \\
3 & 105 & 40 & 170 & 40 & 10.46 & 7.524 \\
4 & 105 & 40 & 130 & 60 & 14.75 & 5.338 \\
5 & 105 & 40 & 150 & 60 & 12.95 & 6.260 \\
6 & 105 & 40 & 170 & 60 & 15.11 & 5.209 \\
7 & 105 & 40 & 130 & 80 & 25.80 & 3.052 \\
8 & 105 & 40 & 150 & 80 & 25.70 & 3.060 \\
9 & 105 & 40 & 170 & 80 & 29.31 & 2.686
\end{tabular}




\begin{tabular}{|c|c|c|c|c|c|c|}
\hline Trial No & $\mathrm{T}_{\text {on }}(\mu \mathrm{s})$ & $\mathrm{T}_{\text {off }}(\mu \mathrm{s})$ & $\mathrm{I}_{\mathrm{P}}(\mathrm{A})$ & $\mathrm{V}_{\mathrm{s}}(\mathrm{V})$ & $\begin{array}{l}\text { Machining time } \\
\text { (min) }\end{array}$ & $\begin{array}{c}\text { MRR } \\
\left(\mathrm{mm}^{3} / \mathrm{min}\right)\end{array}$ \\
\hline 10 & 105 & 50 & 130 & 40 & 19.28 & 4.083 \\
\hline 11 & 105 & 50 & 150 & 40 & 15.46 & 5.090 \\
\hline 12 & 105 & 50 & 170 & 40 & 20.28 & 3.882 \\
\hline 13 & 105 & 50 & 130 & 60 & 22.36 & 3.570 \\
\hline 14 & 105 & 50 & 150 & 60 & 27.75 & 2.837 \\
\hline 15 & 105 & 50 & 170 & 60 & 23.66 & 3.365 \\
\hline 16 & 105 & 50 & 130 & 80 & 46.46 & 1.625 \\
\hline 17 & 105 & 50 & 150 & 80 & 35.21 & 2.240 \\
\hline 18 & 105 & 50 & 170 & 80 & 44.75 & 1.759 \\
\hline 19 & 105 & 60 & 130 & 40 & 31.83 & 2.473 \\
\hline 20 & 105 & 60 & 150 & 40 & 32.50 & 2.580 \\
\hline 21 & 105 & 60 & 170 & 40 & 33.58 & 2.344 \\
\hline 22 & 105 & 60 & 130 & 60 & 45.83 & 1.718 \\
\hline 23 & 105 & 60 & 150 & 60 & 38.96 & 2.040 \\
\hline 24 & 105 & 60 & 170 & 60 & 46.41 & 1.696 \\
\hline 25 & 105 & 60 & 130 & 80 & 66.38 & 1.186 \\
\hline 26 & 105 & 60 & 150 & 80 & 68.86 & 1.143 \\
\hline 27 & 105 & 60 & 170 & 80 & 68.93 & 1.141 \\
\hline 28 & 115 & 40 & 130 & 40 & 4.56 & 17.240 \\
\hline 29 & 115 & 40 & 150 & 40 & 4.50 & 18.103 \\
\hline 30 & 115 & 40 & 170 & 40 & 4.75 & 16.578 \\
\hline 31 & 115 & 40 & 130 & 60 & 5.98 & 15.440 \\
\hline 32 & 115 & 40 & 150 & 60 & 5.48 & 14.362 \\
\hline 33 & 115 & 40 & 170 & 60 & 4.96 & 17.194 \\
\hline 34 & 115 & 40 & 130 & 80 & 10.76 & 7.314 \\
\hline 35 & 115 & 40 & 150 & 80 & 8.33 & 9.603 \\
\hline 36 & 115 & 40 & 170 & 80 & 10.20 & 7.720 \\
\hline 37 & 115 & 50 & 130 & 40 & 5.96 & 14.110 \\
\hline 38 & 115 & 50 & 150 & 40 & 6.15 & 12.800 \\
\hline 39 & 115 & 50 & 170 & 40 & 13.75 & 14.610 \\
\hline 40 & 115 & 50 & 130 & 60 & 9.88 & 7.967 \\
\hline 41 & 115 & 50 & 150 & 60 & 8.08 & 9.780 \\
\hline 42 & 115 & 50 & 170 & 60 & 9.57 & 8.275 \\
\hline 43 & 115 & 50 & 130 & 80 & 15.56 & 5.133 \\
\hline 44 & 115 & 50 & 150 & 80 & 10.91 & 7.214 \\
\hline 45 & 115 & 50 & 170 & 80 & 13.75 & 5.855 \\
\hline 46 & 115 & 60 & 130 & 40 & 10.76 & 7.314 \\
\hline 47 & 115 & 60 & 150 & 40 & 9.35 & 8.550 \\
\hline 48 & 115 & 60 & 170 & 40 & 10.25 & 7.682 \\
\hline 49 & 115 & 60 & 130 & 60 & 14.58 & 5.487 \\
\hline 50 & 115 & 60 & 150 & 60 & 15.56 & 5.059 \\
\hline 51 & 115 & 60 & 170 & 60 & 13.53 & 5.910 \\
\hline 52 & 115 & 60 & 130 & 80 & 28.28 & 2.784 \\
\hline 53 & 115 & 60 & 150 & 80 & 24.20 & 3.265 \\
\hline 54 & 115 & 60 & 170 & 80 & 29.29 & 2.688 \\
\hline 55 & 125 & 40 & 130 & 40 & 6.60 & 11.931 \\
\hline 56 & 125 & 40 & 150 & 40 & 5.76 & 13.657 \\
\hline 57 & 125 & 40 & 170 & 40 & 6.50 & 12.115 \\
\hline 58 & 125 & 40 & 130 & 60 & 5.33 & 14.232 \\
\hline 59 & 125 & 40 & 150 & 60 & 5.61 & 14.660 \\
\hline 60 & 125 & 40 & 170 & 60 & 5.66 & 13.898 \\
\hline 61 & 125 & 40 & 130 & 80 & 6.36 & 12.370 \\
\hline
\end{tabular}




\begin{tabular}{ccccccc}
\hline Trial No & $\mathrm{T}_{\text {on }}(\mu \mathrm{s})$ & $\mathrm{T}_{\text {off }}(\mu \mathrm{s})$ & $\mathrm{I}_{\mathrm{P}}(\mathrm{A})$ & $\mathrm{V}_{\mathrm{s}}(\mathrm{V})$ & $\begin{array}{c}\text { Machining time } \\
(\mathrm{min})\end{array}$ & $\begin{array}{c}\text { MRR } \\
\left(\mathrm{mm}^{3} / \mathrm{min}\right)\end{array}$ \\
\hline 62 & 125 & 40 & 150 & 80 & 5.93 & 13.273 \\
63 & 125 & 40 & 170 & 80 & 6.21 & 12.668 \\
64 & 125 & 50 & 130 & 40 & 5.23 & 15.050 \\
65 & 125 & 50 & 150 & 40 & 6.20 & 12.867 \\
66 & 125 & 50 & 170 & 40 & 5.75 & 13.695 \\
67 & 125 & 50 & 130 & 60 & 6.20 & 12.867 \\
68 & 125 & 50 & 150 & 60 & 5.56 & 14.148 \\
69 & 125 & 50 & 170 & 60 & 5.33 & 15.144 \\
70 & 125 & 50 & 130 & 80 & 8.80 & 8.948 \\
71 & 125 & 50 & 150 & 80 & 7.01 & 11.230 \\
72 & 125 & 50 & 170 & 80 & 7.66 & 10.272 \\
73 & 125 & 60 & 130 & 40 & 6.23 & 12.634 \\
74 & 125 & 60 & 150 & 40 & 5.65 & 13.938 \\
75 & 125 & 60 & 170 & 40 & 5.51 & 14.276 \\
76 & 125 & 60 & 130 & 60 & 8.28 & 9.507 \\
77 & 125 & 60 & 150 & 60 & 7.05 & 10.870 \\
78 & 125 & 60 & 170 & 60 & 25.80 & 11.170 \\
79 & 125 & 60 & 130 & 80 & 12.38 & 6.359 \\
80 & 125 & 60 & 150 & 80 & 12.01 & 6.553 \\
81 & 125 & 60 & 170 & 80 & 12.66 & 6.217 \\
\hline
\end{tabular}

The relationship between input parameters and MRR is illustrated in Figure 4 . Figure 4 evidently shows on increasing $\mathrm{T}_{\text {on }}$ value MRR increases and attains maximum value when $\mathrm{T}_{\text {on }}=125 \mu \mathrm{s}$. The reason behind increase in MRR is increase in discharge energy. This outcome is accordance to the finding of Kanlayasiri et al. [24]. From Figure 4 it is observed that $T_{\text {off }}$ is having contrary effects on MRR. It is evident that the resulting MRR value decreases with increase in $T_{\text {off }}$ value. The duration of discharge get shorter when we increase $T_{\text {off }}$ value. It is apparent from Figure 4 that MRR value gradually increases with decrease in $\mathrm{V}_{\mathrm{s}}$ and attain highest value for lowest $\mathrm{V}_{\mathrm{s}}$ value i.e. $40 \mathrm{~V}$. The MRR value increases with decrease in $\mathrm{V}_{\mathrm{s}}$ because at lower value of $\mathrm{V}_{\mathrm{s}}$ the dielectric strength of the dielectric medium decreases resulting in increase in discharge current during machining. It results in higher melting and evaporation of the workpiece material and hence, MRR increases. It is also evident from Figure 4 that increasing $I_{p}$ upto certain value decreases the MRR, and further increase in $I_{p}$ increases the value of MRR. $I_{p}$ increases the number of electrons striking the work surface thus eroding out more material from the work surface per discharge [25, 26]. SEM analysis has been also conducted to obtain better insight of the surface integrity aspects of WEDMed surface. For this purpose, two samples are selected; first one is the outcome of cutting conditions corresponding to low discharge energy (LDE) $\left(\mathrm{T}_{\text {on }}=105 \mu \mathrm{s}, \mathrm{T}_{\text {off }}=60 \mu \mathrm{s}, \mathrm{I}_{\mathrm{p}}=150 \mathrm{~A}\right.$ and $\mathrm{V}_{\mathrm{s}}=60 \mathrm{~V}$ ) and the second one is the outcome of cutting conditions corresponding to high discharge energy $(\mathrm{HDE})\left(\mathrm{T}_{\mathrm{on}}=115 \mu \mathrm{s}, \mathrm{T}_{\text {off }}=40 \mu \mathrm{s}, \mathrm{I}_{\mathrm{p}}=150 \mathrm{~A}, \mathrm{~V}_{\mathrm{s}}=40 \mathrm{~V}\right)$. 


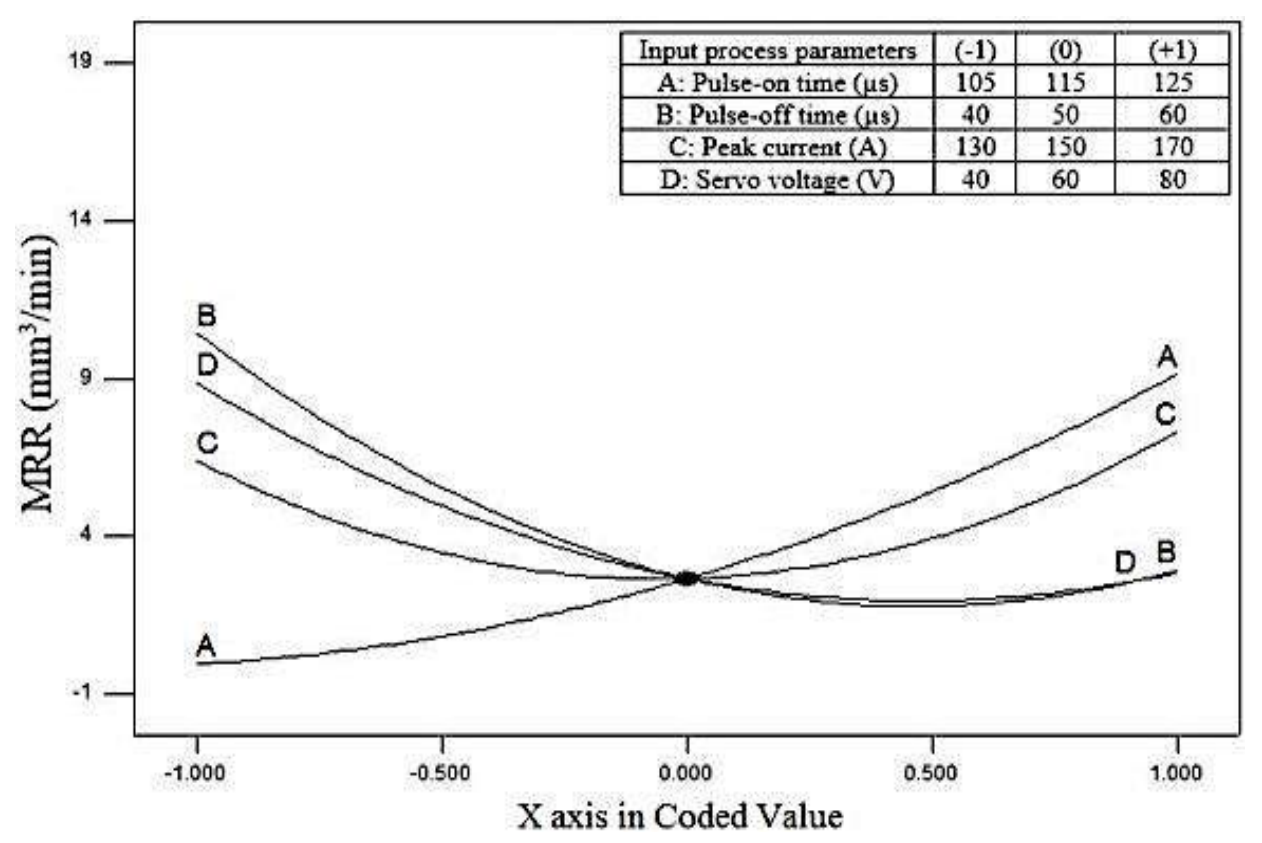

Figure 4. Relationship between input variables and process performance characteristic

SEM micrographs of WEDMed surface corresponding to LDE is depicted in Figure 5 (a) while SEM micrographs of WEDMed surface corresponding to HDE is depicted in Figure 5 (b). Figure 5 clearly confirms that the machined surface corresponding to HDE contains higher amount of craters, deep holes and cracks than the machined surface corresponding to LDE. It is owing to the fact that a high discharge energy result in high value of erosive power Vaporizes a large amount of material causes deep holes and cracks. Thus, the MRR value increases with increase in discharge energy in expense of surface quality of the machined surface. In addition, HDE accelerates the depletion of wire tool material; residual particles of wire tool material get stick to the cutting surface and results in formation of rough surfaces.
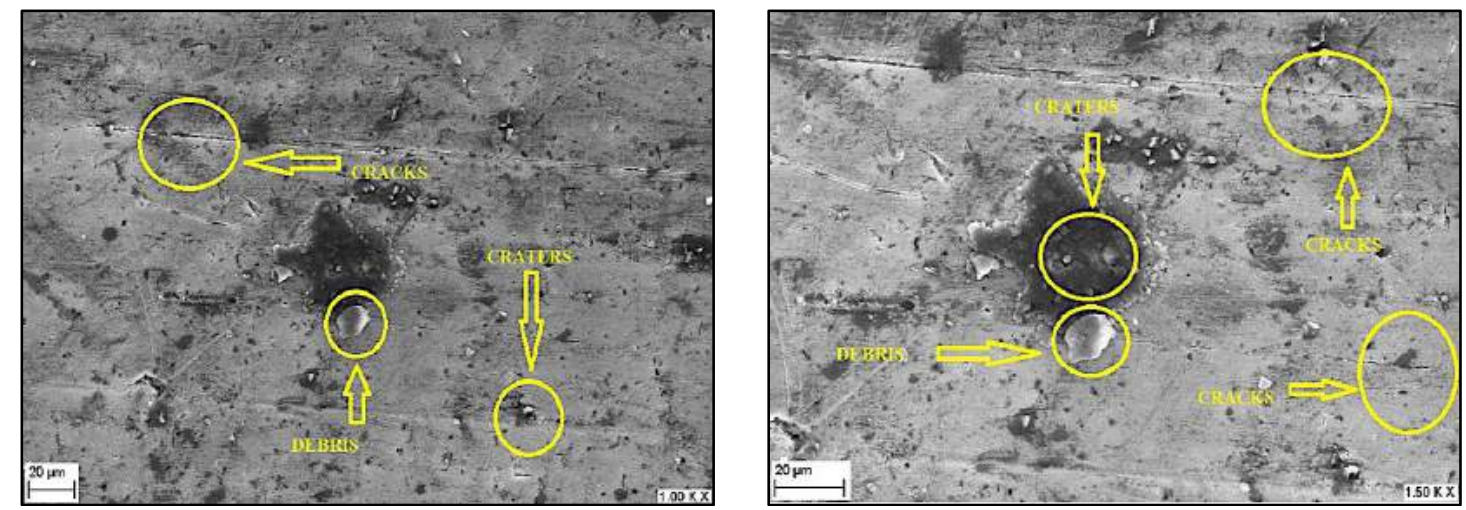

(a) WEDMed surface at LDE $\left(\mathrm{T}_{\text {on }}=115 \mu \mathrm{s}, \mathrm{T}_{\text {off }}=40 \mu \mathrm{s}, \mathrm{I}_{\mathrm{p}}=150 \mathrm{~A}, \mathrm{~V}_{\mathrm{s}}=40 \mathrm{~V}\right)$ 

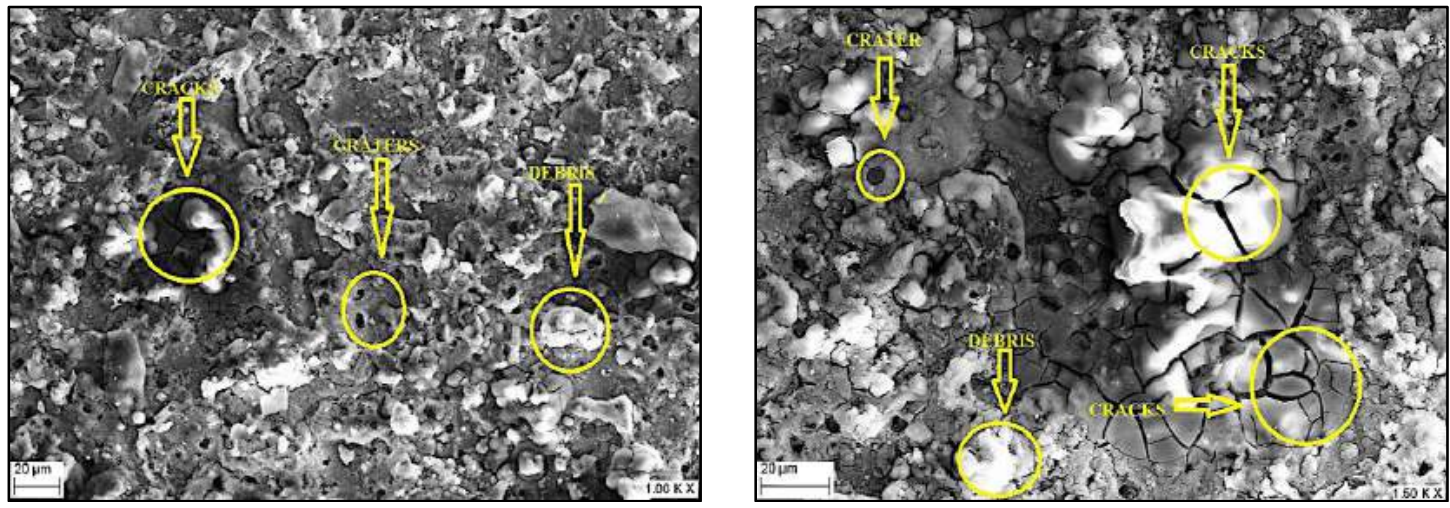

(b) WEDMed surface at HDE $\left(T_{\text {on }}=115 \mu \mathrm{s}, T_{\text {off }}=40 \mu \mathrm{s}, I_{p}=150 \mathrm{~A}, V_{\mathrm{s}}=40 \mathrm{~V}\right)$

Figure 5. SEM micrographs of WEDMed surface at (a) LDE and (b) HDE

\section{ANFIS MODELLING}

To develop the Neuro-fuzzy model, the MATLAB (ANFIS) environment was used due to its inherent available features. The ANFIS system is designed as Multiple Input Single Output System consisting of four inputs and one output. The system under consideration has four input i.e. $\mathrm{V}_{\mathrm{s}}, \mathrm{T}_{\mathrm{on}}, \mathrm{T}_{\text {off }}$ and $\mathrm{I}_{\mathrm{p}}$, and one output material removal rate. Three membership functions were assigned to each of the inputs. The ANFIS procedure starts by presenting the training data obtained from experiments and a number of member functions. The design of four inputs ANFIS is shown in Figure 6. To a first order, four inputs ANFIS model, a typical fuzzy if then rules of Takagi and Sugeno type is as follows.

Rule 1: If $\alpha$ is $A_{1}, \beta$ is $B_{1}, v$ is $C_{1}$ and $\gamma$ is $D_{1}$ then $f_{1}=\left(p_{1} \alpha+q_{1} \beta+r_{1} v+s_{1} \gamma+t_{1}\right)$. The detail of each layer is given below.

Layer 1: Every single node in this layer is a square node, with a node function, $\mathrm{O}_{\mathrm{i}}^{1}=\mu_{\mathrm{A}_{\mathrm{i}}}(\theta)$ where $\theta$ is the input to node $i$, and $A_{i}$, is the linguistic label associated with this node function. In this architecture $\mu_{\mathrm{A}_{\mathrm{i}}}(\theta)$ is bell shaped with maximum equal to 1 and minimum equal to 0 as in Eq. (2):

$$
\mu_{\mathrm{A}_{\mathrm{i}}}(\theta)=\frac{1}{1+\left[\left(\frac{\theta-\mathrm{c}_{\mathrm{i}}}{\mathrm{A}_{\mathrm{i}}}\right)^{2}\right]^{\mathrm{b}_{\mathrm{i}}}}
$$

where, $\left\{a_{i}, b_{i}, c_{i}\right\}$ are the premise parameters.

Layer 2: The function of node in this layer is to multiply the incoming signals and send the product of all inputs. For instance, in Eq. (3).

$$
\begin{aligned}
& \mathrm{w}_{\mathrm{i}}=\mu_{\mathrm{A}_{\mathrm{j}}}(\alpha) \times \mu_{\mathrm{B}_{\mathrm{k}}}(\beta) \times \mu_{\mathrm{C}_{1}}(\mathrm{v}) \times \mu_{\mathrm{D}_{\mathrm{m}}}(\gamma) \\
& \mathrm{i}=1,2 \ldots \ldots \ldots . .81 \\
& \mathrm{j}=1,2,3 \\
& k=1,2,3 \\
& \mathrm{l}=1,2,3
\end{aligned}
$$


$\mathrm{m}=1,2,3$

Each node output represents the firing strength of a rule.

Layer 3: In this layer, the input firing strength of each rule is normalized by dividing with the sum of firing strength of all rules and output is called normalized firing strength. It is calculated using Eq. (4).

$$
\overline{\mathrm{w}_{\mathrm{i}}}=\frac{\mathrm{w}_{\mathrm{i}}}{\mathrm{w}_{1}+\mathrm{w}_{2}+\ldots \ldots \ldots \mathrm{w}_{81}}, \mathrm{i}=1,2,3 \ldots \ldots . .81
$$

Layer 4: Every node $i$ in this layer is a parameterized function. The node function is given by the relation shown in Eq. (5).

$$
\mathrm{O}_{\mathrm{i}}^{4}=\overline{\mathrm{w}}_{\mathrm{i}} \mathrm{f}_{\mathrm{i}}=\overline{\mathrm{w}}_{\mathrm{i}}\left(\mathrm{p}_{\mathrm{i}} \alpha+\mathrm{q}_{\mathrm{i}} \beta+\mathrm{r}_{\mathrm{i}} v+\mathrm{s}_{\mathrm{i}} \gamma+\mathrm{t}_{\mathrm{i}}\right)
$$

where, $\mathrm{i}=1,2 \ldots \ldots 81$ and $\overline{w_{l}}$ is the output of previous layer, and $\left\{p_{i}, q_{i}, r_{i}, s_{i}, t_{i}\right\}$ is a parameter set. Parameters in this layer are referred as consequent parameters.

Layer 5: The single node in this layer calculates the summation of all incoming signals to provide the overall output and quantified using Eq. (6).

$$
\mathrm{O}_{1}^{5}=\text { overall output }=\sum_{\mathrm{i}} \mathrm{w}_{\mathrm{i}} \mathrm{f}_{\mathrm{i}}
$$

The learning comprises of forward and backward passes. The consequent parameters are determined by the method of least squares in the forward pass of the learning algorithm whereas the premise parameters are updated by gradient descent in the backward pass. The overall output is expressed as linear combinations of the consequence parameters. The output $f$ can be rewritten as shown in Eq. (7) and Eq. (7.1).

$$
\begin{aligned}
& \mathrm{f}=\sum_{\mathrm{i}=1}^{81} \overline{\mathrm{w}}_{\mathrm{i}} \mathrm{f}_{\mathrm{i}} \\
& \mathrm{f}=\sum_{\mathrm{i}=1}^{81}\left(\overline{\mathrm{w}}_{1} \alpha\right) \mathrm{p}_{\mathrm{i}}+\left(\overline{\mathrm{w}}_{1} \beta\right) \mathrm{q}_{\mathrm{i}}+\left(\overline{\mathrm{w}}_{1} v\right) \mathrm{r}_{\mathrm{i}}+\left(\overline{\mathrm{w}}_{1} \gamma\right) \mathrm{s}_{\mathrm{i}}+\left(\overline{\mathrm{w}}_{1}\right) \mathrm{t}_{\mathrm{i}}
\end{aligned}
$$




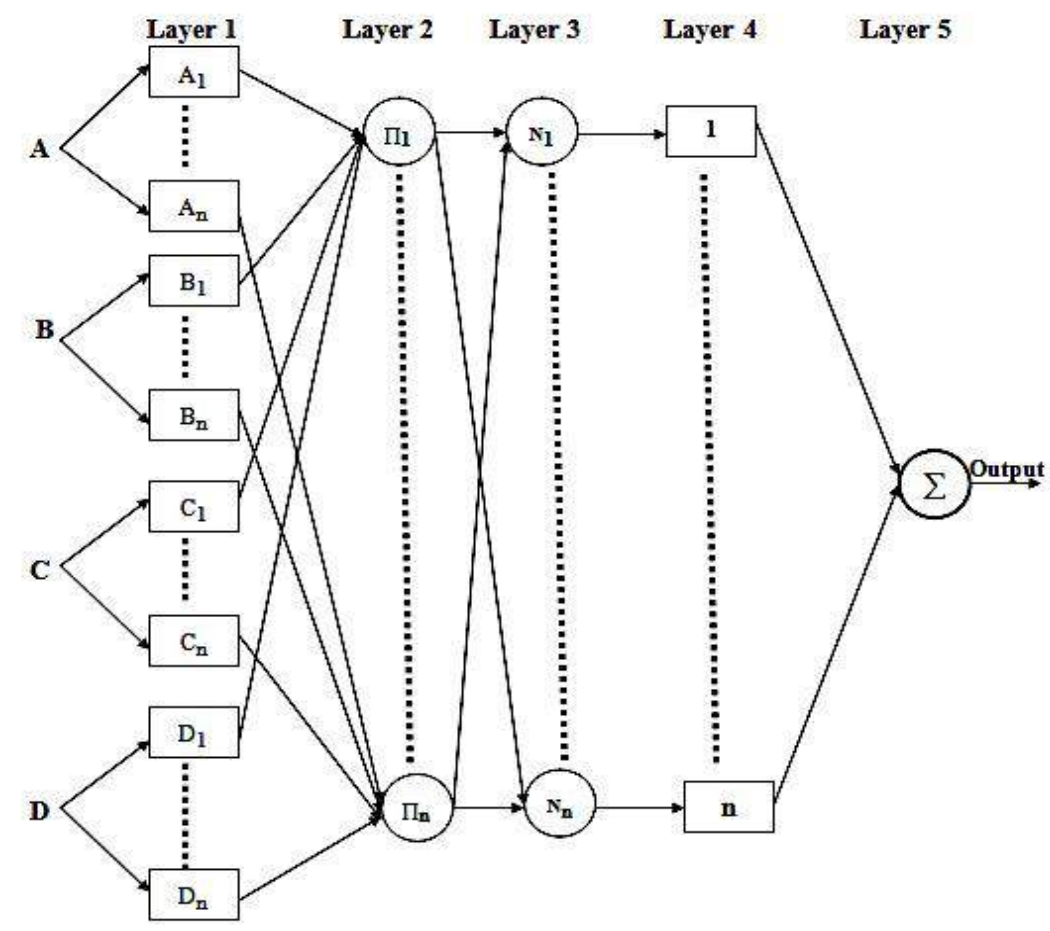

Figure 6. Architecture of four inputs and one output ANFIS

This is linear in the consequent parameters [27-32]. In order to develop an ANFIS model, various membership functions such as gauss, gbell, trapezoidal and triangular functions were tried. The ANFIS training information is as follows.
a) No. of nodes: 193
b) No. of linear parameters: 405
c) No. of nonlinear parameters: 36
d) Total No. of parameters: 441
e) No. of training data pairs: 81
f) No. of checking data pairs: 40
g) No. of fuzzy rules: 81

The trained ANFIS model where then checked with validation data which was not used in training phase to ensure the prediction ability of developed models. The predicted values of various models with different membership functions and their corresponding percentage errors are presented in Table 3. It is evident that triangular membership functions is most appropriate to represent the input output relationship of the presented data as it provides least average percentage error and maximum error. 
Table 3. Comparison of ANFIS output with various membership functions.

\begin{tabular}{|c|c|c|c|c|c|c|c|c|c|}
\hline No & 1 & 2 & 3 & 4 & 5 & 6 & 7 & 8 & $\begin{array}{c}\text { Ave. } \\
\% \\
\text { error }\end{array}$ \\
\hline $\mathrm{T}_{\mathrm{on}} \quad(\mu \mathrm{s})$ & 110 & 120 & 115 & 115 & 115 & 125 & 125 & 125 & \\
\hline $\mathrm{T}_{\text {off }} \quad(\mu \mathrm{s})$ & 50 & 60 & 45 & 55 & 60 & 40 & 50 & 60 & \\
\hline $\mathrm{I}_{\mathrm{p}} \quad(\mathrm{A})$ & 130 & 150 & 170 & 130 & 140 & 160 & 130 & 150 & \\
\hline$(\mathrm{V})$ & 40 & 40 & 40 & 60 & 60 & 60 & 50 & 70 & \\
\hline MRR exp. & 7.797 & 10.887 & 16.464 & 5.913 & 5.048 & 14.275 & 15.242 & 7.835 & \\
\hline $\begin{array}{l}\text { MRR pred. } \\
\text { gbellmf }\end{array}$ & 13.805 & 13.151 & 16.328 & 6.773 & 5.227 & 14.397 & 14.294 & 9.532 & \\
\hline $\begin{array}{l}\text { MRR pred. } \\
\text { gausssmf }\end{array}$ & 13.138 & 11.738 & 15.889 & 6.487 & 5.247 & 14.317 & 14.086 & 8.838 & \\
\hline $\begin{array}{l}\text { MRR pred. } \\
\text { trimf }\end{array}$ & 7.748 & 11.320 & 15.608 & 6.692 & 5.275 & 14.267 & 13.910 & 8.588 & \\
\hline $\begin{array}{l}\text { MRR pred. } \\
\text { trap }\end{array}$ & 9.040 & 11.215 & 15.590 & 6.744 & 5.272 & 14.277 & 13.934 & 8.743 & \\
\hline $\begin{array}{l}\% \text { error } \\
\text { gbellmf }\end{array}$ & 77.06 & 20.8 & 0.83 & 14.55 & 3.56 & 0.86 & 6.21 & 21.67 & 18.19 \\
\hline $\begin{array}{l}\text { \% error } \\
\text { gaussmf }\end{array}$ & 68.50 & 7.82 & 3.49 & 9.71 & 3.95 & 0.30 & 7.58 & 12.81 & 14.27 \\
\hline $\begin{array}{l}\% \text { error } \\
\text { trapmf }\end{array}$ & 15.95 & 3.02 & 5.31 & 14.07 & 4.45 & 0.02 & 8.58 & 11.59 & 7.87 \\
\hline$\%$ error trimf & 0.63 & 3.98 & 5.20 & 13.18 & 4.50 & 0.05 & 8.74 & 9.61 & 5.73 \\
\hline
\end{tabular}

\section{CONCLUSION}

The current research work is consisting of development of an ANFIS model in order to mapping a relationship between input process parameters and process performance characteristic during Wire-EDM of ballistic grade AA 6063. Four different membership functions are tried to develop the model and the triangular membership function is found to be the best. SEM micrographs of machined surfaces corresponding to high discharge energy and low discharge energy have been carried out. Higher value of MRR i.e. $18.103 \mathrm{~mm}^{3} / \mathrm{min}$ is achieved for $\mathrm{T}_{\mathrm{on}}=115 \mu \mathrm{s}, \mathrm{T}_{\text {off }}=40 \mu \mathrm{s}, \mathrm{I}_{\mathrm{p}}=150 \mathrm{~A}$, and $\mathrm{V}_{\mathrm{s}}=40 \mathrm{~V}$; while, lower value of MRR is obtained when $T_{\text {on }}=105 \mu \mathrm{s}, T_{\text {off }}=60 \mu \mathrm{s}, I_{p}=170 \mathrm{~A}$, and $\mathrm{V}_{\mathrm{s}}=80 \mathrm{~V}$. It is apparent that there is near about $94 \%$ improvement in MRR value owing to suitable setting of machining parameters. Although, it is observed that the surface quality is deteriorated in case of high discharge energy. And hence, a careful study is further required to determine the maximum value of MRR that will not affect the surface integrity. In addition, the future research work could consider the study of metallurgical and tribological properties of machined surface to critically evaluate the effect of discharge energy on work surface.

\section{REFERENCES}

[1] Ali MY, Banu A, Salehan M, Adesta EYT, Hazza M, Shaffiq M. Dimensional accuracy in dry micro wire electrical discharge machining. Journal of Mechanical Engineering and Sciences, 2018; 12(1): 3321-3329.

[2] Kumar A, Kumar V, Kumar J. Investigation of machining characterization for wire wear ratio \& MRR on pure titanium in WEDM process through response 
surface methodology. Journal of Process Mechanical Engineering, 2018; 232(1): 108-126.

[3] Jamson EC. Electrical Discharge Machining. Michigan: E-Publishing Inc; 2001.

[4] Mahapatra SS, Patnaik A. Parametric optimization of wire electrical discharge machining (WEDM) process using Taguchi method. International Journal of Advanced Manufacturing and Technology, 2007; 9-10:911-925.

[5] Reddy VC, Deepthi N, Jayakrishna N. Multiple response optimization of Wire EDM on Aluminium HE30 by using Grey Relational Analysis. In: 4th International Conference on Materials Processing and Characterization, Hyderabad, India, pp. 2548-2554; 2015.

[6] Singh B, Misra JP. DAAAM International Scientific Book. A critical review of wire electric discharge machining, 2016, p 249-266.

[7] Shandilya P, Jain PK, Misra JP. DAAAM International Scientific Book. Experimental investigation during wire electric discharge cutting of SICP/6061 aluminum metal matrix composite, 2010, p 1091-1092.

[8] Ho KH, Newman ST, Rahimifard S, Allen RD. State of the art in wire electrical discharge machining (WEDM). International Journal of Machine Tools \& Manufacture, 2004; 44(12): 1247-1259

[9] Shandilya P, Jain PK, Jain NK. On wire breakage and microstructure in WEDC of $\mathrm{SiCp} / 6061$ aluminum metal matrix composites. International Journal of Advanced Manufacturing and Technology, 2012; 61(9-12): 1199-1207.

[10] Singh R, Singh B. Comparison of Cryo treatment effect on machining characteristics of titanium in electric discharge machining. International Journal of Automotive and Mechanical Engineering, 2011; 3: 239-248.

[11] Mohanty S, Routara BC. A review on machining of metal matrix composites using nanoparticle mixed dielectric in electro-discharge machining. International Journal of Automotive and Mechanical Engineering, 2016; 13(2): 3518-3539.

[12] Sarkar S, Ranjan R, Das A. Optimization of machine process parameters on material removal rate in EDM for AISI P20 tool Steel material using RSM. Journal of Material Science and Mechanical Engineering, 2015; 2(2): 117-122.

[13] Krishnan SA, Samuel GL. Multi-objective optimization of material removal rate and surface roughness in wire electrical discharge turning. International Journal of Advanced Manufacturing and Technology, 2013; 67(9-12): 2021-2032.

[14] Khan IA, Rajput TS. Modeling of Wire Electrical Discharge Machining of alloy Steel (HCHCr). International Journal of Precision Engineering and Manufacturing, 2012; 13(11): 1989-1995.

[15] Kumar A, Kumar V, Kumar J. Multi-response optimization of process parameters based on response surface methodology for pure titanium using WEDM process. International Journal of Advanced Manufacturing and Technology, 2013; 68(9-12): 2645-2668.

[16] Ikram A, Mufti NA, Saleem MQ, Khan AR. Parametric optimization for surface roughness, kerf and MRR in wire electrical discharge machining (WEDM) using Taguchi design of experiment. Journal of Mechanical Science and Technology, 2013; 27 (7): 2133-2141.

[17] Singh V, Bhandari R, Yadav VK. An experimental investigation on machining parameters of AISI D2 steel using WEDM. International Journal of Advanced Manufacturing and Technology, 2017; 93(1-4): 203-214. 
[18] Gopal, PM, Prakash KS, Jayaraj S. WEDM of Mg/CRT/BN composites: Effect of materials and machining parameters. Materials and Manufacturing Processes, 2017; 33(1): 77-84.

[19] Saha A, Mondal SC. Experimental investigation and modelling of WEDM process for machining nano-structured hardfacing material. Journal of the Brazilian Society of Mechanical Sciences and Engineering, 2017; 39(9): 34393455.

[20] Unune DR, Mali HS. Experimental investigation on low-frequency vibration assisted micro-WEDM of Inconel 718. Engineering Science and Technology, an International Journal, 2017; 20(1): 222-231.

[21] Kumar V, Jangra KK, Kumar V, Sharma N. WEDM of nickel based aerospace alloy: optimization of process parameters and modelling. International Journal on Interactive Design and Manufacturing, 2017; 11(4): 917-929.

[22] Satishkumar D, Kanthababu M, Vajjiravelu V, Anburaj R, Sundarrajan NT, Arul $\mathrm{H}$. Investigation of wire electrical discharge machining characteristics of Al6063/SiCp composites. International Journal of Advanced Manufacturing and Technology, 2011; 56(9-11): 975-986.

[23] Singh T, Misra JP, Singh B. Experimental Investigation of Influence of Process Parameters on MRR during WEDM of Al6063 alloy. 5th International Conference of Materials Processing and Characterization Materials Today: Proceedings, Hyderabad, India, pp. 2242-2247; 2016.

[24] Kanlayasiri K, Boonmung S. An investigation on effects of wire-EDM machining parameters on surface roughness of newly developed DC53 die steel. Journal of Materials Processing and Technology, 2007; 187-188: 26-29.

[25] Goswami A, Kumar J. Optimization in wire-cut EDM of Nimonic-80A using Taguchi's approach and utility concept. Engineering Science and Technology: An International Journal, 2014; 17(4): 236-246.

[26] Goswami A, Kumar J. Trim cut machining and surface integrity analysis of Nimonic 80A alloy using wire cut EDM. Engineering Science and Technology, an International Journal, 2017; 20(1): 175-186.

[27] Sharma RS, Upadhyay V, Hans Raj K. Neuro-fuzzy modeling of hot closed die forging of an automotive piston for agile manufacturing. Journal of Institution of Engineers (India), 2008; 88, 42-48.

[28] Caydas U, Hascalik A, Ekici S. An adaptive neuro-fuzzy inference system (ANFIS) model for wire-EDM. Expert Systems with Applications, 2009; 36(3): 6135-6139.

[29] Azhiri RB, Teimouri R, Baboly MG, Leseman Z. Application of Taguchi, ANFIS and grey relational analysis for studying, modeling and optimization of wire EDM process while using gaseous media. International Journal of Advanced Manufacturing and Technology, 2014; 71(1-4): 279-295.

[30] Sharma H, Komal UK, Singh I, Kumar D, Misra JP. Artificial Intelligence based tool for predicting of damage during drilling of FRP's. 21st International Conference on Composite Materials, Xi'an, 20-25th August 2017.

[31] Sarkheyli A, Zain AM, Sharif S. A multi-performance prediction model based on ANFIS and new modified-GA for machining processes. Journal of intelligent manufacturing, 2015; 26(4): 703-716.

[32] Aldas K, Ozkul I, Akkurt A. Modelling surface roughness in wedm process using anfis method. Journal of the Balkan Tribological Association, 2014; 20(4): 548-558. 